\title{
Narasin improves ewe milk yield efficiency and may affect performance of lambs
}

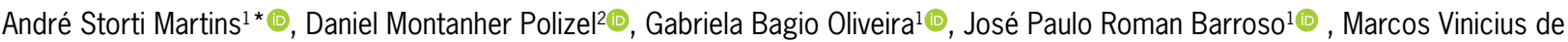

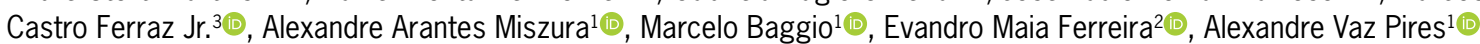

\author{
1Universidade de São Paulo/FMVZ - Depto. de Nutrição e \\ Produção Animal, Av. Duque de Caxias Norte, 225 - 13635- \\ 900 - Pirassununga, SP - Brasil. \\ 2Universidade de São Paulo/ESALQ - Depto. de Zootecnia, \\ C.P. 09 - 13418-900 - Piracicaba, SP - Brasil. \\ 3Universidade Federal do Amazonas - Depto. de Zootecnia, \\ Av. Parintins Macurany, 1805 - 69152-240 - Parintins, AM \\ - Brasil. \\ *Corresponding author <andre.storti.martins@gmail.com>
}

Edited by: Antonio Faciola

Received October 23, 2020

Accepted January 19, 2021
ABSTRACT: Adding ionophores to ruminant diets is a strategy to manipulate ruminal fermentation and improve milk yield. This study evaluates the effects of narasin supply to lactating ewes on dry matter intake (DMI), milk yield and composition, and performance of the lambs. Thirty lactating Santa Inês and Santa Inês $\times$ Dorper ewes fed a basal diet containing $50 \%$ coastcross hay and $50 \%$ concentrate were randomly assigned to two treatments: control (CON; without ionophores) or NAR (addition of $13 \mathrm{mg}$ narasin $\mathrm{kg}^{-1} \mathrm{DM}$ ). From the $2^{\text {nd }}$ to $10^{\text {th }}$ week of lactation, DMl of ewes was determined, and once a week, their milk production and composition was measured over a 3-h interval. At the $10^{\text {th }}$ week of lactation, lambs were weaned and their average daily gain (ADG) and starter DMl continued to be evaluated for two more weeks. Narasin supply did not affect weight and DMI of ewes. Ewes fed NAR had greater feed efficiency for milk production and displayed tendency for higher milk yield. Narasin supply reduced milk protein levels, but it did not affect other milk component levels. Ewes fed NAR had greater production of milk urea nitrogen and showed tendency for higher production of fat and total solids. Starter DMI of lambs was not affected by treatments; however, there was a tendency for greater weaning weight for NAR lambs. At the end of experiment, no differences were observed in the performance of lambs. The supply of $13 \mathrm{mg}$ narasin $\mathrm{kg}^{-1}$ to lactating ewes improved milk yield efficiency and tended to increase the weaning weight of their lambs.

Keywords: ionophores, lactation, lambs, milk composition, sheep

\section{Introduction}

During the first weeks of life, lambs do not have complete ruminal development, and milk is their main feed source (Godfrey et al., 1997; Torres-Hernandez and Hohenboken, 1980). Milk intake is essential for healthy development and may affect weaning weight and performance of lambs (Morgan et al., 2007). Studies have demonstrated that higher milk production from Santa Inês ewes resulted in greater average daily gain (ADG) for lambs until weaning (Araujo et al., 2008; Ferreira et al., 2014). In addition, a reduction in creep feeding intake of lambs may occur when milk production from Santa Inês ewes is increased (Araujo et al., 2008).

The supply of ionophores to ruminant diets manipulates the ruminal fermentation, enhancing energy retention and $\mathrm{N}$ utilization (Russel and Strobel, 1989; Tedeschi et al., 2003). There is an increase in propionate availability, resulting in better energetic balance and greater milk yield (Oba and Allen, 2003). Many studies evaluated the use of ionophores for dairy cows (McGuffey et al., 2001) or finishing beef cattle diets (Duffield et al., 2012); however, little is known about ionophores use for lactating ewes.

Narasin is an ionophore approved by the Brazilian Ministry of Agriculture, Livestock, and Supply in 2015 (MAPA, 2020) for use as feed additive for ruminants. Since its approval, several studies have been conducted and demonstrated the positive effects of narasin on ruminal fermentation (Pasqualino et al., 2020; Polizel et al., 2020) and animal performance (Gobato et al., 2020; Polizel et al., 2021a). To our knowledge, the only studies that evaluated the use of narasin in lactating ewes demonstrated its potential to increase milk yield and efficiency when ewes were fed diets with ground corn as main energy source (Assis et al., 2020) or a mix of ground corn and citrus pulp (Sardinha et al., 2020).

This study evaluated the use of narasin in the diet of lactating ewes fed diets with a mix of ground corn and soybean hulls as the main energy source, its effect on DMI, milk yield and composition, and on the performance of their offspring. We hypothesized that the use of narasin addition to the diet of lactating ewes increases milk yield, without affecting DMI. Thus, lambs from ewes receiving narasin may present greater weight gain with lower DMI of starter.

\section{Materials and Methods}

This study was conducted in Piracicaba, state of São Paulo, Brazil $\left(22^{\circ} 43^{\prime} 0^{\prime \prime} \mathrm{S}, 47^{\circ} 38^{\prime} 51^{\prime \prime} \mathrm{W}\right.$, altitude $\left.528 \mathrm{~m}\right)$. All procedures using animals followed the guidelines recommended by the Animal Care and Use Committee of the University of São Paulo (protocol number 6972020119).

\section{Animals and Experimental Design}

Thirty Santa Inês $(\mathrm{n}=12)$ and Santa Inês $\times$ Dorper $(\mathrm{n}=18)$ ewes $[61.97 \pm 2.24 \mathrm{~kg}$ of initial body weight $(\mathrm{BW})]$ with up to two weeks of lactation $(10.6 \pm 0.5 \mathrm{~d})$, were housed indoor and individually allotted with their lambs $(6.73 \pm 0.38 \mathrm{~kg}$ of initial BW $)$ in pens $(1.3 \times 3.5$ $\mathrm{m})$, which had a concrete floor, a feed bunk, a mineral box, a waterer and creep-feeding system $(0.80 \times 1.0$ 
m). Sixteen ewes had single births ( 8 male and 8 female lambs), and 14 gave birth to twins ( 6 female-female and 8 male-female pairs of lambs), totaling 28 female and 16 male lambs.

At lambing day, ewes and lambs were identified and weighted. Ewes were dewormed with $10 \mathrm{mg} \mathrm{kg}^{-1}$ of moxidectin and $2.5 \mathrm{mg} \mathrm{kg}^{-1}$ of monepantel.

After $10.6 \pm 0.5 \mathrm{~d}$ of lactation, ewes were divided into a randomized complete block design with two treatments and 15 blocks. The blocks (2 ewes each) were defined according to date of lambing, type of birth (single or twin), offspring sex, and initial BW of ewes. Ewes within a block were randomly assigned to an experimental diet. The experimental period was from $2^{\text {nd }}$ to $10^{\text {th }}$ week postpartum for ewes and their lambs were evaluated until the $12^{\text {th }}$ week of age.

\section{Diets and feed management}

For a week, previously to the beginning of the experiment, ewes received the control diets containing $500 \mathrm{~g} \mathrm{~kg}^{-1}$ of dry matter (DM) of coastcross (Cynodon dactylon (L.) Pers) hay and $500 \mathrm{~g} \mathrm{~kg}^{-1}$ of DM of concentrate to adapt them to the experimental facilities and feeding management. The experimental diets were formulated to be isonitrogenous and balanced according to the National Research Council (NRC, 2007) recommendations for lactating ewes. The treatments comprised a control diet, without additives (CON), or the same basal diet, with $13 \mathrm{mg}$ of narasin $\mathrm{kg}^{-1}$ of DM (NAR; Zimprova, Elanco Animal Health, São Paulo, SP, Brazil). The proportion of the ingredients and the chemical composition of the diets are presented in Table 1.

The concentrate ingredients were mixed using a horizontal mixer with a capacity of $500 \mathrm{~kg}$. The coastcross hay was chopped using a shredder with a $10-\mathrm{mm}$ sieve. Narasin was previously mixed with the concentrate for NAR treatment. Samples from chopped hay and each concentrate mixture were collected and stored at $-20^{\circ} \mathrm{C}$ for further analyses. The concentrate and the coastcross hay were weighed separately, manually mixed, and offered daily to each ewe.

Experimental diets were fed as total mixed rations daily in the morning and animals were allowed access ad libitum to feed and fresh water. The amounts of feed offered to ewes were adjusted daily according to previous DMI, allowing $5 \%$ of the feed offered as refusal. Orts were recorded every week to determine the DMI and samples were composited by treatment and stored at $-20{ }^{\circ} \mathrm{C}$ for further analyses.

Ewes were weighed without fasting for three consecutive days at the beginning of the experimental period and at the $10^{\text {th }}$ week of lactation, when lambs were weaned. The initial BW and final BW were determined as the average of 3-day data. On days of weighing, the body condition score (BCS) was also assessed by classifying ewes with grades from 1 (thin) to 5 (fat), with an increment of 0.25 (Russel et al., 1969).
Table 1 - Proportions of ingredients and chemical composition of experimental diets fed to Santa Inês and Santa Inês $\times$ Dorper lactating ewes.

\begin{tabular}{|c|c|c|}
\hline \multirow{2}{*}{ Item $^{2}$} & \multicolumn{2}{|c|}{ Diets $^{1}$} \\
\hline & CON & NAR \\
\hline \multicolumn{3}{|l|}{ Ingredient proportion } \\
\hline Coastcross hay ( $\mathrm{g} \mathrm{kg}^{-1}$ of DM) & 500 & 500 \\
\hline Ground corn ( $\mathrm{g} \mathrm{kg}^{-1}$ of DM) & 230 & 230 \\
\hline Soybean hulls (g kg-1 of DM) & 230 & 230 \\
\hline Soybean meal ( $\mathrm{g} \mathrm{kg}^{-1}$ of DM) & 20 & 20 \\
\hline Mineral $\mathrm{mix}^{3}\left(\mathrm{~g} \mathrm{~kg}^{-1}\right.$ of DM) & 10 & 10 \\
\hline Urea ( $\mathrm{g} \mathrm{kg}^{-1}$ of DM) & 5 & 5 \\
\hline Limestone ( $\mathrm{g} \mathrm{kg}^{-1}$ of DM) & 5 & 5 \\
\hline Narasin ${ }^{4} \mathrm{mg} \mathrm{kg}^{-1}$ of DM) & 0 & 13 \\
\hline \multicolumn{3}{|l|}{ Chemical composition } \\
\hline Dry matter (g kg-1 as fed) & 884.0 & 894.0 \\
\hline Organic matter ( $\mathrm{g} \mathrm{kg}^{-1}$ of DM) & 938.2 & 939.4 \\
\hline Crude protein ( $\mathrm{g} \mathrm{kg}^{-1}$ of DM) & 151.9 & 158.0 \\
\hline Neutral detergent fiber (g kg-1 of DM) & 438.8 & 454.0 \\
\hline Acid detergent fiber ( $\mathrm{g} \mathrm{kg}^{-1}$ of DM) & 269.0 & 286.0 \\
\hline Ether extract ( $\mathrm{g} \mathrm{kg}^{-1}$ of DM) & 17.6 & 20.7 \\
\hline Ash (g kg-1 of DM) & 61.8 & 60.6 \\
\hline Non-fiber carbohydrates ( $\mathrm{g} \mathrm{kg}^{-1}$ of DM) & 329.9 & 306.8 \\
\hline \multicolumn{3}{|c|}{ 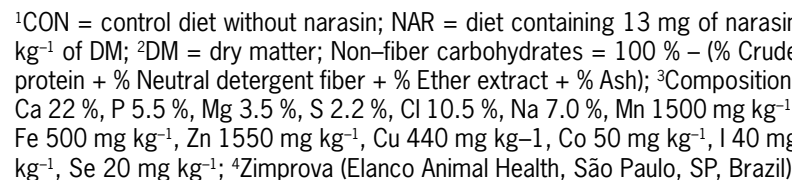 } \\
\hline
\end{tabular}

\section{Milk yield and composition}

Weekly, ewes were separated from their lambs and milked twice with a 3-h interval between milkings. For the first milking, lambs were withdrawn from the pens, and ewes were milked mechanically, after intravenous injection of 10 International Units (IU) of synthetic oxytocin to stimulate milk ejection. The first milking emptied the mammary gland and the milk was discarded. After $3 \mathrm{~h}$, without interaction with the lambs, ewes were milked a second time, after a new intravenous injection of $10 \mathrm{IU}$ of synthetic oxytocin. At this milking, milk production was weighed on an electronic scale accurate to $0.1 \mathrm{~g}$ to quantify milk production during 3 $\mathrm{h}$ (Susin et al., 1995) and milk samples $(20 \mathrm{~mL})$ from each ewe were preserved in bromopol (2-bromo-2nitropropane-1.3-diol). The samples were analyzed for protein, fat, lactose, total solids (TS), solids nonfat (SNF) and milk urea nitrogen (MUN), determined by midinfrared spectrometry (ISO 9622:2013/ IDF 141:2013).

Milk correction calculations for fat $(6.5 \%$; fatcorrected milk, FCM) and protein (5.8\%; fat and proteincorrected milk, FPCM) were performed as described by Pulina and Nudda (2004). Feed efficiency [FE; (g of milk) (g of DMI $)^{-1}$ ] was calculated for milk yield, FCM, and FPCM considering the DMI each week, and a $24 \mathrm{~h}$ milk yield estimate was accessed by multiplying production in $3 \mathrm{~h}$ by a factor of 8 . 


\section{Blood parameters}

Blood samples were collected from the jugular vein of ewes weekly, $4 \mathrm{~h}$ after feeding. For the insulin analysis, vacuum tubes with inert separator gel for serum were used. To determine urea and glucose, blood was collected in vacuum tubes containing sodium fluoride as a glycolytic inhibitor and anticoagulant EDTA. Blood samples were centrifuged at $3000 \times \mathrm{g}$ at $4^{\circ} \mathrm{C}$ for $15 \mathrm{~min}$. After centrifugation, aliquots were obtained from the plasma and serum and stored at $-20^{\circ} \mathrm{C}$. Serum insulin concentration was determined by chemiluminescence immunoassay using components of commercial kits. Plasma glucose and urea were determined using specific commercial enzymatic kits in an automatic biochemistry system.

\section{Performance of lambs}

Lambs had access ad libitum to starter concentrate from $2^{\text {nd }}$ to $12^{\text {th }}$ week of age, available in a creep feeding system. The starter was composed by $630 \mathrm{~g} \mathrm{~kg}^{-1}$ of ground corn, $215 \mathrm{~g} \mathrm{~kg}^{-1}$ of soybean meal, $10 \mathrm{~g} \mathrm{~kg}^{-1}$ of mineral mix, 13 $\mathrm{g} \mathrm{kg}^{-1}$ of limestone, $32 \mathrm{~g} \mathrm{~kg}^{-1}$ of molasses, and $100 \mathrm{~g} \mathrm{~kg}^{-1}$ of milk replacer. The chemical composition analyzed ( $\mathrm{g}$ $\mathrm{kg}^{-1} \mathrm{DM}$ ) of starter was: $880 \mathrm{~g} \mathrm{DM}$ (g kg-1, as-fed basis), $214 \mathrm{~g} \mathrm{CP}, 129 \mathrm{~g} \mathrm{NDF}, 57 \mathrm{~g}$ ash, and $36 \mathrm{~g}$ fat. Lambs were kept in a leash system to prevent ewes from accessing the feed bunk, which length permitted free access to the creep feeder and fresh water and allowing them to nurse (Parente et al., 2018; Polizel et al., 2017). Lambs were weighed weekly after 3-h fasting to calculate ADG. DMI starter was recorded during pre-weaning $\left(2^{\text {nd }}\right.$ to $10^{\text {th }}$ week of age) and post-weaning $\left(11^{\text {th }}\right.$ to $12^{\text {th }}$ week of age) periods.

\section{Chemical Analysis}

At the end of the experiment, samples of feed, orts and starter concentrate were dried in a forced-air oven at $60{ }^{\circ} \mathrm{C}$ for $72 \mathrm{~h}$, ground through a $1-\mathrm{mm}$ screen of a Willey-type mill and analyzed for DM at $105^{\circ} \mathrm{C}$ (AOAC, 1990; \# 934.01). Ash concentration was obtained by incinerating the samples in a muffle at $550{ }^{\circ} \mathrm{C}$ for $4 \mathrm{~h}$ (AOAC, 1990; \# 942.05). The sequential detergent fiber analyses were used to determine neutral detergent fiber (NDF; Van Soest et al., 1991) and acid detergent fiber (ADF; Goering and Van Soest, 1970) concentrations with a fiber analyzer instrument. Heat-stable $\alpha$-amylase and sodium sulfite were included to the NDF analysis. Total N concentration was determined according to combustion method (AOAC, 1990; \# 968.06) and crude protein (CP) was calculated by multiplying total $\mathrm{N}$ by 6.25 . The ether extract (EE) concentration was determined according to AOAC (1990; \# 920.29). Nonfiber carbohydrates (NFC) of the diets were estimated according to the following equation: $\mathrm{NFC}=100 \%-(\% \mathrm{CP}+\% \mathrm{NDF}+\% \mathrm{EE}+$ $\%$ Ash).

\section{Statistical Analysis}

Statistical procedures were conducted using the MIXED procedure in SAS (Statistical Analysis System, version 9.4). All data were submitted to the Shapiro-Wilk test to verify the normality of residuals. The Levene test was used to verify the homogeneity of variances and outliers were removed using the studentized residuals. The data that did not respect these premises were subjected to logarithmic, inverse, or square root transformation. The pen was the experimental unit for all statistical analyses.

Nutrient intake, milk yield and composition, and metabolic profile data were analyzed as repeated measurements over time. The statistical model used was: $\mathrm{Y}_{\mathrm{ijk}}=\mu+\mathrm{B}_{\mathrm{i}}+\mathrm{D}_{\mathrm{j}}+\mathrm{E}_{\mathrm{ij}}+\mathrm{T}_{\mathrm{k}}+(\mathrm{BT})_{\mathrm{ik}}+(\mathrm{DT})$ ${ }_{j k}+E_{i j k}$ where: $\mu=$ overall mean, $B_{i}=$ random block effect ( $\mathrm{i}=1$ to 15$), D_{j}=$ fixed effect of diet $(j$ $=1$ to 2$), \mathrm{E}_{\mathrm{ij}}=$ random error $\mathrm{A}, \mathrm{T}_{\mathrm{k}}=$ fixed effect of time $(\mathrm{k}=1$ to 8$),(\mathrm{BT})_{\mathrm{ik}}=$ random effect of block $\times$ time interaction, $(\mathrm{DT})_{\mathrm{jk}}=$ fixed effect of diet $\times$ time interaction, and $\mathrm{E}_{\mathrm{ijk}}=$ random error $\mathrm{B}$. All data analyzed as repeated measures were put on covariance matrices and tested for "Compound Symmetry, Heterogeneous Compound Symmetry, Unstructured, Banded, Toeplitz, Autoregressive, Variance Components, Banded Toeplitz, Heterogeneous Autoregressive, Autoregressive Moving Average, Factor Analytic, Huynh-Feldt, Antedependence, Heterogeneous Toeplitz and Unstructured using Correlations". Due to the lower value obtained for Akaike's information criterion, the covariance matrix used was the "Autoregressive Moving Average" [ARMA $(1,1)]$. The LSMEANS command obtained the treatment means. The $\mathrm{F}$ test defined the effect of diet, time, and interaction of diet $\times$ time.

The BW and BCS of ewes, BW of lambs, and DMI starter were analyzed using the model $\mathrm{Y}_{\mathrm{ij}}=\mu+\mathrm{B}_{\mathrm{i}}+$ $D_{j}+E_{i j}$. Where: $\mu=$ overall mean, $B_{i}=$ random block effect $(i=1$ to 15$), D_{j}=$ fixed effect of $\operatorname{diet}(j=1$ to 2 ), and $\mathrm{Eij}=$ random error. The LSMEANS command obtained the treatment means. The $\mathrm{F}$ test defined the treatment effect. All analyzed variables were considered significant when $p \leq 0.05$ and tendency when $0.05<p$ $\leq 0.10$.

At the end of the $2^{\text {nd }}$ week post-partum, blood samples were collected before the ewes started to receive the experimental diets and the ewes were milked as described previously to obtain milk yield and composition before the experiment. These data were used as covariate for the statistical analysis.

\section{Results}

There was no interaction between diet and time for any of the variables studied.

The data on BW, BCS, and DMI of ewes are shown in Table 2. There was no difference between treatments for BW, BCS, or for their variation along the experiment. 
The addition of narasin to the diet did not affect DM, $\mathrm{NDF}$, and CP intakes. However, there was effect on time for all intake variables $(p<0.01)$ as expected, with an increase from the $3^{\text {rd }}$ to $4^{\text {th }}$ week of lactation and then a slight decrease from $5^{\text {th }}$ to $6^{\text {th }}$ week, remaining steady until the end of lactation (Figure 1).

The initial data on milk yield and composition used as covariate were significant $(p<0.05)$ for all milk measurements. Narasin addition showed a tendency to improve milk yield ( $p=0.09)$, as presented in Table 3. Milk composition was not altered by diets for milk fat, lactose, TS, SNF, and MUN levels; however, NAR decreased protein concentration $(p=0.02)$. There was no effect of the treatments on FCM and FPCM.

Table 2 - Body weight, body condition score, and nutrient intake of Santa Inês and Santa Inês $\times$ Dorper lactating ewes fed diets without or with narasin from the 3rd to 10th week post-partum.

\begin{tabular}{|c|c|c|c|c|c|c|}
\hline \multirow{2}{*}{ Item $^{2}$} & \multicolumn{2}{|c|}{ Diets $^{1}$} & \multirow{2}{*}{$\mathrm{SEM}^{3}$} & \multicolumn{3}{|c|}{$p$-value ${ }^{4}$} \\
\hline & CON & NAR & & Diet (D) & Time (T) & $D \times T$ \\
\hline \multicolumn{7}{|l|}{ BW (kg) } \\
\hline Week 3 & 62.62 & 61.31 & 2.24 & 0.57 & - & - \\
\hline Week 10 & 63.35 & 61.48 & 2.18 & 0.47 & - & - \\
\hline BW Change & 0.62 & 0.16 & 0.66 & 0.63 & - & - \\
\hline \multicolumn{7}{|l|}{ BCS } \\
\hline Week 3 & 3.33 & 3.15 & 0.14 & 0.22 & - & - \\
\hline Week 10 & 3.41 & 3.25 & 0.13 & 0.17 & - & - \\
\hline BCS Change & 0.03 & 0.10 & 0.09 & 0.43 & - & - \\
\hline \multicolumn{7}{|l|}{ Intake $\left(\mathrm{kg} \mathrm{d}^{-1}\right)$} \\
\hline $\mathrm{DM}$ & 2.59 & 2.66 & 0.07 & 0.54 & $<0.01$ & 0.38 \\
\hline NDF & 1.02 & 1.06 & 0.03 & 0.32 & $<0.01$ & 0.38 \\
\hline $\mathrm{CP}$ & 0.35 & 0.37 & 0.01 & 0.30 & $<0.01$ & 0.40 \\
\hline
\end{tabular}

${ }^{1} \mathrm{CON}=$ control diet without narasin; NAR = diet containing $13 \mathrm{mg}$ of narasin $\mathrm{kg}^{-1}$ of DM (Zimprova, Elanco Animal Health, São Paulo, Brazil). ${ }^{2} \mathrm{BW}=$ body weight; week post-partum; $\mathrm{BCS}=$ body condition score; $\mathrm{DM}=$ dry matter; $\mathrm{NDF}=$ neutral detergent fiber; $\mathrm{CP}=$ crude protein; ${ }^{3} \mathrm{SEM}=$ standard error of the mean; ${ }^{4} p$-value for Diet, Time and Diet $\times$ Time interaction $(D \times T)$.

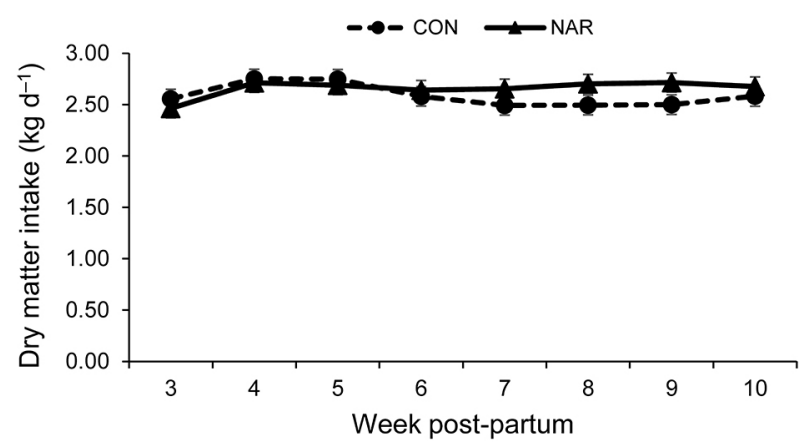

Figure 1 - Dry matter intake of Santa Inês and Santa Inês $\times$ Dorper lactating ewes fed diets without (CON) or with $13 \mathrm{mg}$ of narasin $\mathrm{kg}^{-1}$ of DM (Zimprova; Elanco Animal Health, São Paulo, Brazil; NAR) from the $3^{\text {rd }}$ to $10^{\text {th }}$ week post-partum. Values refer to the least squares mean \pm standard error of the mean. There was no diet and time interaction $(p>0.10)$ and diet effect $(p>0.10)$. There was time effect $(p<0.01)$ with the greater values observed in the $4^{\text {th }}$ week post-partum.
There was no effect of diet on the total production of protein, lactose and SNF; however, ewes fed NAR had a tendency to increase milk fat production $(p=$ $0.06)$ and TS $(p=0.06)$. Ewes from NAR had greater MUN production $(p=0.01)$. Narasin addition improved FE for milk $(p=0.03)$, FCM $(p=0.03)$, and FPCM $(p$ $=0.03$ ).

Effects of time were observed for all milk variables $(p<0.05)$, except for fat and TS composition. Milk yield decreased with advancing days post-lambing (Figure 2). Since milk fat and TS concentrations were not altered through weeks, their total production reduced as well as milk yield. Lactose concentration in milk reduced slightly over time, with the highest content observed in the $3^{\text {rd }}$ week. Milk protein and SNF concentrations increased through lactation, with higher values reached in the $9^{\text {th }}$ and $10^{\text {th }}$ weeks. MUN levels increased from the $3^{\text {rd }}$ to $6^{\text {th }}$ week and were kept until the end of the experiment.

The initial blood data used as covariate were significant $(p<0.05)$ for plasma urea and serum insulin parameters. The covariate adjustment was not used

Table 3 - Milk yield, composition, and feed efficiency of Santa Inês and Santa Inês $\times$ Dorper lactating ewes fed diets without or with narasin from the $3^{\text {rd }}$ to $10^{\text {th }}$ week post-partum.

\begin{tabular}{|c|c|c|c|c|c|c|}
\hline \multirow{2}{*}{ Item } & \multicolumn{2}{|c|}{ Diets $^{1}$} & \multirow{2}{*}{$\mathrm{SEM}^{4}$} & \multicolumn{3}{|c|}{$p$-value ${ }^{5}$} \\
\hline & CON & NAR & & Diet (D) & ) Time (T) & $D \times T$ \\
\hline \multicolumn{7}{|c|}{ Milk yield $\left({\left.\mathrm{g} 3 \mathrm{~h}^{-1}\right)^{2}}^{2}\right.$} \\
\hline Milk & 164.10 & 193.50 & 12.73 & 0.09 & $<0.01$ & 0.70 \\
\hline FCM & 198.90 & 236.90 & 16.17 & 0.10 & $<0.01$ & 0.62 \\
\hline FPCM & 190.10 & 222.20 & 14.71 & 0.10 & $<0.01$ & 0.90 \\
\hline Fat & 14.26 & 17.21 & 1.26 & 0.06 & $<0.01$ & 0.31 \\
\hline Protein & 8.68 & 9.51 & 0.63 & 0.24 & 0.03 & 0.78 \\
\hline Lactose & 7.89 & 9.25 & 0.64 & 0.12 & $<0.01$ & 0.99 \\
\hline TS & 32.23 & 37.71 & 2.60 & 0.06 & $<0.01$ & 0.65 \\
\hline SNF & 17.96 & 20.56 & 1.38 & 0.14 & $<0.01$ & 0.93 \\
\hline MUN (mg $3 h^{-1}$ ) & 38.35 & 49.13 & 3.22 & 0.01 & $<0.01$ & 0.32 \\
\hline \multicolumn{7}{|l|}{ Composition (\%) } \\
\hline Fat & 8.85 & 8.69 & 0.33 & 0.74 & 0.88 & 0.67 \\
\hline Protein & 5.43 & 5.07 & 0.11 & 0.02 & $<0.01$ & 0.56 \\
\hline Lactose & 4.68 & 4.71 & 0.05 & 0.64 & $<0.01$ & 0.99 \\
\hline TS & 19.83 & 19.52 & 0.33 & 0.50 & 0.20 & 0.45 \\
\hline SNF & 11.04 & 10.81 & 0.10 & 0.12 & $<0.01$ & 0.86 \\
\hline MUN (mg dL-1) & 26.22 & 26.49 & 0.69 & 0.78 & $<0.01$ & 0.52 \\
\hline \multicolumn{7}{|l|}{ Feed Efficiency ${ }^{3}$} \\
\hline Milk DMI-1 & 0.49 & 0.59 & 0.03 & 0.03 & $<0.01$ & 0.77 \\
\hline $\mathrm{FCM} \mathrm{DMl}^{-1}$ & 0.59 & 0.71 & 0.04 & 0.03 & $<0.01$ & 0.64 \\
\hline $\mathrm{FPCM} \mathrm{DMl}^{-1}$ & 0.57 & 0.68 & 0.04 & 0.03 & $<0.01$ & 0.67 \\
\hline
\end{tabular}

${ }^{1} \mathrm{CON}=$ control diet without narasin; NAR = diet containing $13 \mathrm{mg}$ of narasin $\mathrm{kg}^{-1}$ of DM (Zimprova, Elanco Animal Health, São Paulo, Brazil); ${ }^{2}$ Milk produced in a 3 -h interval; FCM $=6.5 \%$ fat-corrected milk according to Pulina and Nudda (2004); FPCM $=6.5 \%$ fat-d $5.8 \%$ protein-corrected milk according to Pulina and Nudda (2004); TS = total solids; SNF = solids nonfat; MUN = milk urea nitrogen; ${ }^{3}$ Feed Efficiency: Milk DMl- ${ }^{-1}=$ (g of milk adjusted for $24 \mathrm{~h}$ $\mathrm{g}^{-1}$ of DM intake); FCM DMl-1 = (g of fat-corrected milk adjusted for $24 \mathrm{~h} \mathrm{~g}^{-1}$ of DM intake); FPCM DMI'-1 = (g of fat and protein-corrected milk adjusted for $24 \mathrm{~h} \mathrm{~g}^{-1}$ of DM intake); ${ }^{4} \mathrm{SEM}=$ standard error of the mean; ${ }^{5} p$-value for Diet, Time and Diet $\times$ Time interaction $(\mathrm{D} \times \mathrm{T})$. 


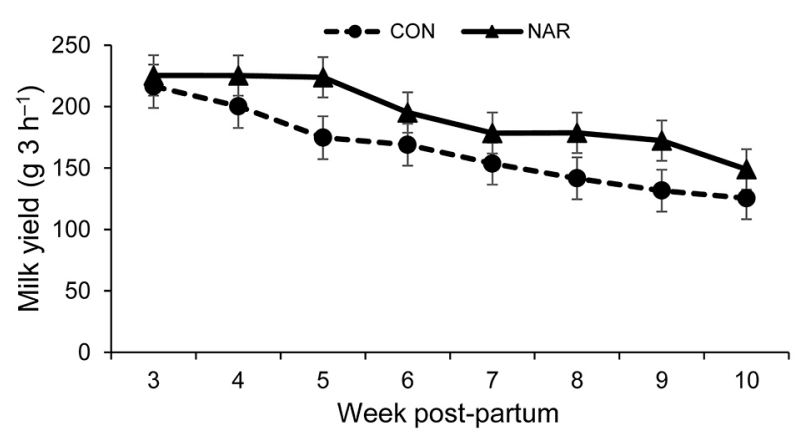

Figure 2 - Milk yield in a 3-h interval from Santa Inês and Santa Inês $\times$ Dorper lactating ewes fed diets without (CON) or with $13 \mathrm{mg}$ of narasin $\mathrm{kg}^{-1}$ of DM (Zimprova; Elanco Animal Health, São Paulo, Brazil; NAR) from the $3^{\text {rd }}$ to $10^{\text {th }}$ week post-partum. Values refer to the least squares mean \pm standard error of the mean. There was no diet and time interaction $(p>0.10)$. There was a tendency for NAR addition to increase milk yield $(p=0.09)$. There was time effect ( $p<0.01$ ), as milk yield decreased with advancing weeks post-lambing.

Table 4 - Blood metabolites of Santa Inês and Santa Inês $\times$ Dorper lactating ewes fed diets without or with narasin from the $3^{\text {rd }}$ to $10^{\text {th }}$ week post-partum.

\begin{tabular}{lccccccc}
\hline \multirow{2}{*}{ Item $^{2}$} & \multicolumn{2}{c}{ Diets $^{1}$} & \multirow{2}{*}{ SEM $^{3}$} & \multicolumn{3}{c}{ p-value $^{4}$} \\
\cline { 2 - 3 } \cline { 6 - 7 } & CON & NAR & & Diet (D) & Time (T) & $\mathrm{D} \times \mathrm{T}$ \\
\hline Glucose $\left(\mathrm{mg} \mathrm{dL}^{-1}\right)$ & 68.51 & 72.43 & 2.57 & & 0.23 & $<0.01$ & 0.52 \\
Urea $\left(\mathrm{mg} \mathrm{dL}^{-1}\right)$ & 57.91 & 56.23 & 1.56 & & 0.38 & $<0.01$ & 0.25 \\
Insulin $\left(\mu \mathrm{Ul} \mathrm{mL}^{-1}\right)$ & 15.22 & 14.64 & 1.98 & 0.58 & 0.06 & 0.53 \\
\hline
\end{tabular}

${ }^{1} \mathrm{CON}=$ control diet without narasin; NAR = diet containing $13 \mathrm{mg}$ of narasin $\mathrm{kg}^{-1}$ of DM (Zimprova, Elanco Animal Health, São Paulo, Brazil); ${ }^{2}$ Plasma concentrations of glucose and urea; serum concentration of insulin; ${ }^{3}$ SEM $=$ standard error of the mean; ${ }^{4} p$-value for Diet, Time and Diet $\times$ Time interaction $(\mathrm{D} \times \mathrm{T})$.

for plasma glucose. Blood parameters of ewes were not affected by the treatments (Table 4). Nevertheless, effects of time were observed for plasma glucose and urea levels $(p<0.01)$, with greater glucose values in the $7^{\text {th }}$ and $8^{\text {th }}$ week of lactation (Figure 3), and greater urea values reached in the $5^{\text {th }}$ week of lactation (Figure $4)$. There was a tendency $(p=0.06)$ for time effect for serum insulin level (Figure 5).

There was a tendency $(p=0.08)$ for greater BW at weaning of lambs from NAR, although no differences in ADG were observed. At the end of the experiment $\left(12^{\text {th }}\right.$ week), there was no difference in BW of lambs in any of the treatments (Table 5). DMI starter of lambs along the experiment was not affected by the treatments, either during lactation or after weaning.

\section{Discussion}

The ewes maintained or gained weight and BCS during the experimental period, indicating that the diets and DMI were sufficient to meet the nutritional requirements of lactation.

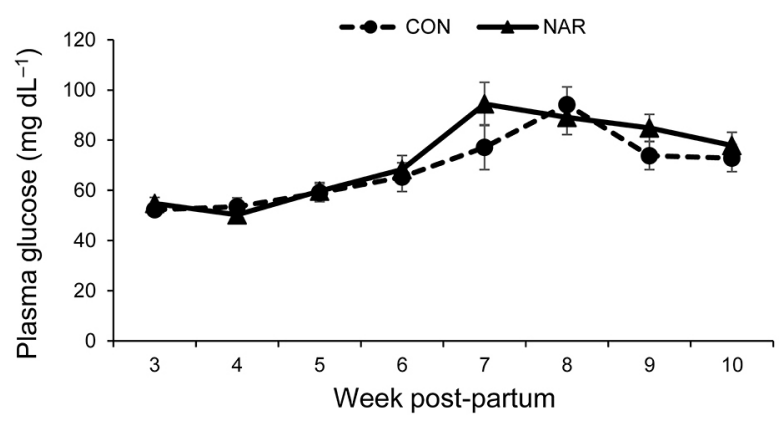

Figure 3 - Plasma glucose concentration of Santa Inês and Santa Inês $\times$ Dorper lactating ewes fed diets without (CON) or with 13 mg of narasin $\mathrm{kg}^{-1}$ of DM (Zimprova; Elanco Animal Health, São Paulo, Brazil; NAR) from the $3^{\text {rd }}$ to $10^{\text {th }}$ week post-partum. Values refer to the least squares mean \pm standard error of the mean. There was no diet and time interaction $(p>0.10)$ and diet effect ( $p$ $>0.10)$. There was time effect $(p<0.01)$, with the greater values observed in the $7^{\text {th }}$ and $8^{\text {th }}$ weeks post-partum.

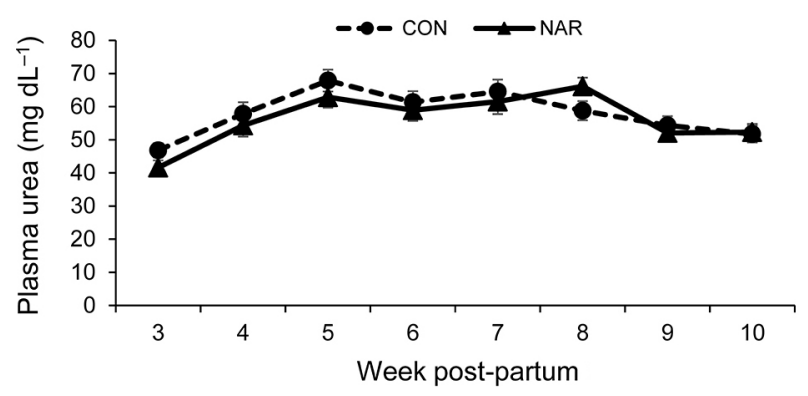

Figure 4 - Plasma urea concentration of Santa Inês and Santa Inês $\times$ Dorper lactating ewes fed diets without (CON) or with $13 \mathrm{mg}$ of narasin $\mathrm{kg}^{-1}$ of DM (Zimprova; Elanco Animal Health, São Paulo, Brazil; NAR) from the $3^{\text {rd }}$ to $10^{\text {th }}$ week post-partum. Values refer to the least squares mean \pm standard error of the mean. There was no diet and time interaction $(p>0.10)$ and diet effect $(p>0.10)$. There was time effect $(p<0.01)$ with the greater values observed in the $5^{\text {th }}$ week post-partum.

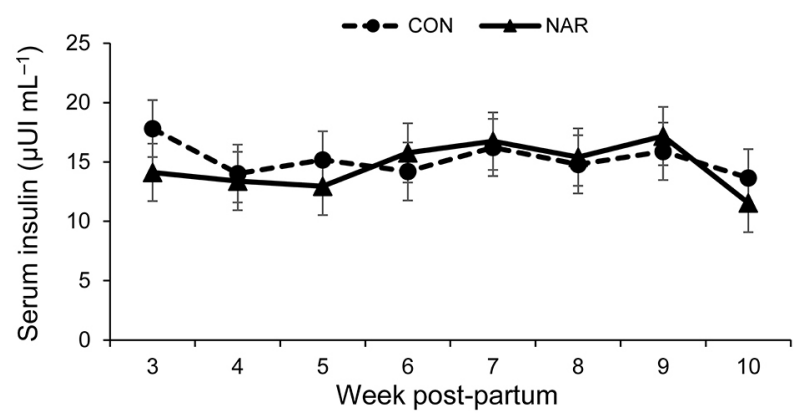

Figure 5 - Serum insulin concentration of Santa Inês and Santa Inês $\times$ Dorper lactating ewes fed diets without (CON) or with $13 \mathrm{mg}$ of narasin $\mathrm{kg}^{-1}$ of DM (Zimprova; Elanco Animal Health, São Paulo, Brazil; NAR) from the $3^{\text {rd }}$ to $10^{\text {th }}$ week post-partum. Values refer to the least squares mean \pm standard error of the mean. There was no diet and time interaction $(p>0.10)$ and diet effect $(p>0.10)$. There was tendency for time effect $(p=0.06)$. 
Table 5 - Body weight, average daily gain, and starter intake of lambs from Santa Inês and Santa Inês $\times$ Dorper lactating ewes fed diets without or with narasin during lactation and post-weaning period.

\begin{tabular}{|c|c|c|c|c|}
\hline \multirow{2}{*}{ Item $^{2}$} & \multicolumn{2}{|c|}{ Diets $^{1}$} & \multirow{2}{*}{$\mathrm{SEM}^{3}$} & \multirow{2}{*}{$p$-value ${ }^{4}$} \\
\hline & $\mathrm{CON}$ & NAR & & \\
\hline \multicolumn{5}{|c|}{ Body weight (kg) } \\
\hline Initial & 6.69 & 6.77 & 0.38 & 0.83 \\
\hline Weaning & 20.38 & 21.45 & 0.71 & 0.08 \\
\hline Final & 25.11 & 25.76 & 0.95 & 0.38 \\
\hline \multicolumn{5}{|l|}{ ADG (kg) } \\
\hline Pre-weaning & 0.24 & 0.26 & 0.01 & 0.12 \\
\hline Post-weaning & 0.34 & 0.31 & 0.03 & 0.30 \\
\hline Total & 0.26 & 0.27 & 0.02 & 0.51 \\
\hline \multicolumn{5}{|c|}{ Starter DMI (kg) } \\
\hline Pre-weaning & 11.96 & 11.62 & 1.03 & 0.73 \\
\hline Post-weaning & 10.43 & 10.12 & 0.84 & 0.73 \\
\hline Total & 22.32 & 21.74 & 1.71 & 0.70 \\
\hline
\end{tabular}

${ }^{1} \mathrm{CON}=$ ewes received a control diet without narasin; NAR $=$ ewes received a diet containing $13 \mathrm{mg}$ of narasin $\mathrm{kg}^{-1}$ of DM (Zimprova, Elanco Animal Health, São Paulo, Brazil); ${ }^{2}$ nitial = body weight at the $3^{\text {rd }}$ week post-partum; Weaning $=10^{\text {th }}$ week post-partum; Final $=12^{\text {th }}$ week post-partum; Pre-weaning $=$ period from the $3^{\text {rd }}$ to $10^{\text {th }}$ week post-partum; Post-weaning $=$ period from the $11^{\text {th }}$ to $12^{\text {th }}$ week post-partum; Total = experimental period from the $3^{\text {rd }}$ to $12^{\text {th }}$ week post-partum; ${ }^{3} \mathrm{SEM}=$ standard error of the mean; ${ }^{4} \mathrm{p}$-value for Diet effect.

The use of ionophores in ruminant diets is usually associated to a reduction in DM consumption, especially when monensin is used (Duffield et al., 2012; Polizel et al., 2021b). On the other hand, recent studies evaluating the use of narasin in ruminant diets indicate that this ionophore does not reduce DMI when added to diets with high levels of roughage (Pasqualino et al., 2020; Polizel et al., 2020) or concentrate (Polizel et al., 2021a). Moreover, Assis et al. (2020) related that when supplied at a dose of $13 \mathrm{mg} \mathrm{kg}^{-1}$ of DM, narasin increased DMI of lactating ewes. This narasin characteristic may be important to avoid DMI reduction in a production period already physiologically affected. As the addition of narasin did not affect DMI in the present study, consumption of NDF and CP was equal for both experimental diets.

The addition of narasin to the diet of lactating ewes tended to increase milk yield by $17.91 \%$. Corroborating these findings, Assis et al. (2020) related that the inclusion of $13 \mathrm{mg}$ narasin $\mathrm{kg}^{-1}$ of DM improved milk production of ewes by $4.58 \%$. Sardinha et al. (2020) also described an increase of $24.5 \%$ in milk production of ewes fed a diet containing $13 \mathrm{mg}$ narasin $\mathrm{kg}^{-1}$ of DM compared to ewes fed the control diet. Altogether, these results suggest that narasin is effective to improve the diet for milk production. Narasin provides an increased proportion of propionate and total volatile fatty acids concentration (Polizel et al., 2020), which characterizes a more energy-efficient rumen fermentation /Oba and Allen, 2003) and may explain the positive effect of narasin on milk production and FE of lactating ewes. Milk, FCM, and FPCM feed efficiency were increased by $20 \%$ for NAR ewes. Sardinha et al. (2020) also related greater FE in ewes supplemented with narasin.

In the present study, the effect of narasin on FE of ewes was greater than the increases caused by ionophores in dairy cows (McGuffey et al., 2001). Santa Inês $\times$ Dorper ewes (Assis et al., 2020) and Santa Inês and Dorper ewes have moderate potential for milk production (Araujo et al., 2008) and the milk produced is intended for feeding the lambs. Thus, these results should be considered with caution, because due to the lower milk yield of these ewes, small increases in production may represent greater percentage of variations than those observed in high production animals, such as dairy cows or dairy ewes. Therefore, these results should not be extrapolated to animals with higher dairy production and further studies are needed for these categories.

The peak and persistence of lactation are controlled by genetic, physiological, seasonal, healthy, and nutritional factors that interact with one another (Pulina et al., 2007). Generally, lactation curves with a higher production peak are less persistent and the milk production rate decreases more quickly in ewes with a marked increase in production in the first days of lactation. The peak of lactation usually occurs between the $3^{\text {rd }}$ and $4^{\text {th }}$ week postpartum (Cardellino and Benson, 2002). In the present study, the lactation peak of ewes that received narasin was more persistent, remaining at higher levels until the $5^{\text {th }}$ week of lactation. In contrast, ewes from the control group showed a reduction in production already in the $3^{\text {rd }}$ week of lactation. Energetic diets usually extend the lactation peak (Zambom et al., 2005). Again, due to its action in selecting ruminal bacteria, narasin can increase the diet energy efficiency, providing greater use for milk production.

Ewes from NAR treatment had lower milk protein content; however, it did not reflect the total protein production, which may have been offset by the greater milk production (Phipps et al., 2000). As reported in lactating cows, the effects of ionophores on milk protein contents are variable (Benchaar et al., 2006; Duffield et al., 2008; Odongo et al., 2007). According to Pulina et al. (2006), one of the main factors that affect the fat and protein content of sheep milk is milk production and the correlations between milk production and the fat and protein levels are negative. Thus, as milk production increases, the synthesis of fat and protein occurs more slowly, resulting in a lower concentration (Emery, 1988).

Although the MUN content did not increase, the supply of narasin increased the total MUN production by $28 \%$ due to the tendency to increase milk yield. Pulina et al. (2006) highlighted that MUN synthesis is related to a greater protein supply for ewes. The effects of improving efficiency in the use of dietary protein from ionophores could increase the post-ruminal protein supply and its excess can be transformed into MUN. There was no effect of narasin on the contents 
of other milk compounds; however, the tendency to greater production of total fat and TS may be related to greater milk production.

Nutritional effects of narasin addition were not enough to affect the metabolic profile of ewes. Plasma glucose, urea, and serum insulin levels show that diets were sufficient to meet the nutritional requirements throughout lactation. Effects of time observed for plasma glucose and urea can be associated to DMI increase from the $3^{\text {rd }}$ to $4^{\text {th }}$ week of lactation and the start of milk yield reduction. The lower concentrations of glucose and urea match with the lactation peak in the $3^{\text {rd }}$ week post-partum, and there is an increase in concentrations along with decreases in milk yield.

Milk is the main nutritional source of lambs in the first days of life. As lambs grow, they increase their intake of solid feeds. During periods of high-energy requirements, milk intake is preferably greater than solid feeds intake (Araujo et al., 2008); thus, greater milk production can reduce consumption of the initial concentrate by lambs.

In the present study, there was no difference in the starter intake during the lactation phase and after weaning. Nevertheless, there was a tendency for greater weaning weight of lambs from ewes supplemented with narasin. Besides the similar starter intake, the NAR lambs were favored by greater milk production, leading to a $5.25 \%$ increase in weaning weight. However, this greater milk production was insufficient to reduce the initial concentrate intake or increase ADG during the entire experiment. Previous studies have shown that the increase in milk production due to the addition of narasin reduced the initial concentrate consumption of lambs (Assis et al., 2020), mainly during the four weeks before weaning, due to less milk production (Sardinha et al., 2020). As lactation progresses, epithelial cells of the mammary gland pass from the active secretion state to the no-secretory state by the involutions processes, characterizing the reduction of milk production at the end of lactation (Pulina and Nudda, 2004), increasing the importance of solid diets for lambs.

\section{Conclusion}

Supplementing $13 \mathrm{mg}$ of narasin $\mathrm{kg}^{-1}$ of DM to diets of lactating ewes improved the FE for milk production. Narasin is an important tool capable of increasing milk yield without affecting DMI. In addition, greater milk yield tended to increase weaning weight of their lambs.

\section{Acknowledgments}

The authors thank the University of São Paulo (USP) for providing the physical infrastructure and staff necessary for this study, and the Coordination for the Improvement of Higher Education Personnel - Brazil (CAPES - Finance Code 001), for providing a scholarship to the first author.

\section{Authors' Contributions}

Conceptualization: Martins, A.S.; Polizel, D.M.; Ferreira, E.M.; Pires, A.V. Data acquisition: Martins, A.S.; Polizel, D.M.; Oliveira, G.B.; Barroso, J.P.R.; Ferraz Jr., M.V.C.; Miszura, A.A. Data analysis: Martins, A.S.; Polizel, D.M. Design of methodology: Polizel, D.M.; Ferraz Jr., M.V.C.; Ferreira, E.M.; Pires, A.V. Writing and editing: Martins, A.S.; Polizel, D.M.; Barroso, J.P.R.; Ferraz Jr., M.V.C.; Baggio, M.

\section{References}

Araujo, R.C.; Pires, A.V.; Susin, I.; Mendes, C.Q.; Rodrigues, G.H.; Packer, I.U.; Eastridge, M.L. 2008. Milk yield, milk composition, eating behavior, and lamb performance of ewes fed diets containing soybean hulls replacing coastcross (Cynodon species) hay. Journal of Animal Science 86: 35113521.

Assis, R.G.; Biava, J.S.; Polizel, D.M.; Souza, T.T.; Sturion, T.U.; Pires, A.V.; Relling, A.E.; Ferreira, E.M. 2020. Use of narasin in diets for lactating ewes. Small Ruminant Research 187: 106-108.

Association of Official Analytical Chemists [AOAC]. 1990. Official Methods of Analysis. 15ed. Arlington, VA, USA.

Benchaar, C.; Petit, H.V.; Berthiaume, R.; Whyte, T.D.; Chouinard, P.Y. 2006. Effects of addition of essential oils and monensin premix on digestion, ruminal fermentation, milk production, and milk composition in dairy cows. Journal of Dairy Science 89: 4352-4364.

Cardellino, R.A.; Benson, M.E. 2002. Lactation curves of commercial ewes rearing lambs. Journal of Animal Science 80: 23-27.

Duffield, T.F.; Merrill, J.K.; Bagg, R.N. 2012. Meta-analysis of the effects of monensin in beef cattle on feed efficiency, body weight gain, and dry matter intake. Journal of Animal Science 90: 4583-4592.

Duffield, T.F.; Rabiee, A.R.; Lean, I.J. 2008. A Meta-analysis of the impact of monensin in lactating dairy cattle. Part 2. Production effects. Journal of Dairy Science 91: 1347-1360.

Emery, R.S. 1988. Milk fat depression and the influence of diet on milk composition. Veterinary Clinics of North America: Food Animal Practice 4: 289-305.

Ferreira, E.M.; Pires, A.V.; Susin, I.; Gentil, R.S.; Gilaverte, S.; Parente, M.O.M.; Biehl, M.V.; Di Mambro Ribeiro, C.V. 2014. Lamb performance, milk production and composition from ewes supplemented with soybean oil partially replaced by fish oil blend. Livestock Science 163: 51-61.

Gobato, L.G.M.; Polizel, D.M.; Ferraz Júnior, M.V.C.; Miszura, A.A.; Barroso, J.P.R.; Martins, A.S.; Gonçalves, J.R.S.; Ferreira, E.M.; Pires, A.V. 2020. Supplementation of grazing beef cattle with narasin. Pesquisa Agropecuária Brasileira 55: e01270.

Godfrey, R.W.; Gray, M.L.; Collins, J.R. 1997. Lamb growth and milk production of hair and wool sheep in a semi-arid tropical environment. Small Ruminant Research 24: 77-83.

Goering, H.K.; Van Soest, P.J. 1970. Forage Fiber Analyses (Apparatus, Reagents, Procedures, and Some Applications). USDA/ARS, Washington, DC, USA. (Agriculture Handbook, $379)$. 
Ministério da Agricultura, Pecuária e Abastecimento [MAPA]. 2020. List of additives approved by MAPA for use in animal feed = Lista de aditivos aprovados pelo MAPA para uso na alimentação animal. Available at: https://www.gov.br/ agricultura/pt-br/assuntos/insumos-agropecuarios/insumospecuarios/alimentacao-animal/arquivos-alimentacao-animal/ Listaaditivos17.03.2020.pdf [Accessed Oct 21, 2020] (in Portuguese).

McGuffey, R.K.; Richardson, L.F.; Wilkinson, J.I.D. 2001. Ionophores for dairy cattle: current status and future outlook. Journal of Dairy Science 84: E194-E203.

Morgan, J.E.; Fogarty, N.M.; Nielsen, S.; Gilmour, A.R. 2007. The relationship of lamb growth from birth to weaning and the milk production of their primiparous crossbred dams. Australian Journal of Experimental Agriculture 47: 899-904.

National Research Council [NRC]. 2007. Nutrient Requirements of Small Ruminants: Sheep, Goats, Cervids and New World Camelids. National Academy Press, Washington, DC, USA.

Oba, M.; Allen, M.S. 2003. Dose-response effects of intrauminal infusion of propionate on feeding behavior of lactating cows in early or midlactation. Journal of Dairy Science 86: 2922-2931.

Odongo, N.E.; Bagg, R.; Vessie, G.; Dick, P.; Or-Rashid, M.M.; Hook, S.E.; Gray, J.T.; Kebreab, E.; France, J.; McBride, B.W. 2007. Long-term effects of feeding monensin on methane production in lactating dairy cows. Journal of Dairy Science 90: 1781-1788.

Parente, M.O.M.; Susin, I.; Nolli, C.P.; Ferreira, E.M.; Gentil, R.S.; Polizel, D.M.; Pires, A.V.; Alves, S.P.; Bessa, R.J.B. 2018. Effects of supplementation with vegetable oils, including castor oil, on milk production of ewes and on growth of their lambs. Journal of Animal Science 96: 354-363.

Pasqualino, L.F.; Oliveira, G.B.; Miszura, A.A.; Barroso, J.P.R.; Limede, A.C.; Sardinha, L.A.; Biava, J.S.; Ferreira, E.M.; Pires, A.V.; Polizel, D.M. 2020. Residual effect of narasin on ruminal fermentation characteristics in lambs. Livestock Science 240: 104141.

Phipps, R.H.; Wilkinson, J.I.D.; Jonker, L.J.; Tarrant, M.; Jones, A.K.; Hodge, A. 2000. Effect of monensin on milk production of holstein-friesian dairy cows. Journal of Dairy Science 83: 2789-2794.

Polizel, D.M.; Cappellozza, B.I.; Hoe, F.; Lopes, C.N.; Barroso, J.P.; Miszura, A.; Oliveira, G.B.; Gobato, L.; Pires, A.V. 2020. Effects of narasin supplementation on dry matter intake and rumen fermentation characteristics of Bos indicus steers fed a high-forage diet. Translational Animal Science 4: 118-128.

Polizel, D.M.; Marques, S.S.; Westphalen, M.F.; Gouvea, V.N.; Ferraz Júnior, M.V.C.; Miszura, A.A.; Barroso, J.P.R.; Limede, A.C.; Ferreira, E.M.; Pires, A.V. 2021a. Narasin inclusion for feedlot lambs fed a diet containing high amounts of ground flint corn. Scientia Agricola 78: e20200010.
Polizel, D.M.; Martins, A.S.; Miszura, A.A.; Ferraz Júnior, M.V.C.; Bertoloni, A.V.; Oliveira, G.B.; Barroso, J.P.R.; Ferreira, E.M.; Pires, A.V. 2021b. Low doses of monensin for lambs fed diets containing high level of ground flint corn. Scientia Agricola 78: e20190263.

Polizel, D.M.; Susin, I.; Gentil, R.S.; Ferreira, E.M.; Souza, R.A.; Freire, A.P.A.; Pires, A.V.; Ferraz, M.V.C.; Rodrigues, P.H.M.; Eastridge, M.L. 2017. Crude glycerin decreases nonesterified fatty acid concentration in ewes during late gestation and early lactation. Journal of Animal Science 95: 875-883.

Pulina, G.; Nudda, A. 2004. Milk production. p. 1-12. In: Pulina, G., ed. Dairy sheep nutrition, CABI, Wallingford, UK.

Pulina, G.; Nudda, A.; Battacone, G.; Cannas, A. 2006. Effects of nutrition on the contents of fat, protein, somatic cells, aromatic compounds, and undesirable substances in sheep milk. Animal Feed Science and Technology 131: 255-291.

Pulina, G.; Nudda, A.; Macciotta, N.P.P.; Battacone, G.; Giacomo Rassu, S.P.; Cannas, A. 2007. Non-nutritional factors affecting lactation persistency in dairy ewes: a review. Italian Journal of Animal Science 6: 115-141.

Russel, A.J.F.; Doney, J.M.; Gunn, R.G. 1969. Subjective assessment of body fat in live sheep. The Journal of Agricultural Science 72: 451-454.

Russel, J.B.; Strobel, H.J. 1989. Effect of lonophores on ruminal fermentation. Applied and Environmental Microbiology 55: 1-6.

Sardinha, L.A.; Marques, R.S.; Miszura, A.A.; Barroso, J.P.R.; Oliveira, G.B.; Martins, A.S.; Limede, A.C.; Ferraz Jr., M.V.C.; Ferreira, E.M.; Pires, A.V; Eastridge, M.L.; Polizel, D.M. 2020. Milk yield and composition from ewes fed diets containing narasin and their lambs' performance. Translational Animal Science 4: 854-862.

Susin, I.; Loerch, S.C.; McClure, K.E. 1995. Effects of feeding a high-grain diet at a restricted intake on lactation performance and rebreeding of ewes. Journal of Animal Science 73: 31993205.

Tedeschi, L.O.; Fox, D.G.; Tylutki, T.P. 2003. Potential Environmental Benefits of Ionophores in Ruminant Diets. Journal of Environmental Quality 32: 1591-1602.

Torres-Hernandez, G.; Hohenboken, W. 1980. Relationships between ewe milk production and composition and preweaning lamb weight gain. Journal of Animal Science 50: 597-603.

Van Soest, P.J.; Robertson, J.B.; Lewis, B.A. 1991. Methods for dietary fiber, neutral detergent fiber, and nonstarch polysaccharides in relation to animal nutrition. Journal of Dairy Science 74: 3583-3597.

Zambom, M.A.; Alcalde, C.R.; Silva, K.T.; Macedo, F.A.F.; Santos, G.T.; Borghi, E.L.; Barbosa, E.D. 2005. Effects of different forage:concentrate ratios on intake, digestibility, and milk yield of saanen goats. Revista Brasileira de Zootecnia 34: 2505-2514 (in Portuguese, with abstract in English). 